\title{
Медико-соціологічне дослідження серед населення об'сднаних територіальних громад Сумської області щодо збереження власного здоров'я
}

\author{
Сумський державний університет, м. Суми, Україна
}

\begin{abstract}
Мета - проаналізувати відношення населення об'єднаних територіальних громад до збереження власного здоров'я, профілактики неінфекційних захворювань та пріоритетних питань в охороні здоров'я громади.

Матеріали та методи. Форма дослідження - опитування за допомогою закритої анкети. Дослідження проводилося за спеціально розробленою трирівневою пропориійною вибіркою, яка розраховувалась з врахуванням територіальних $i$ соціально-демографічних показників. Всього за пропориійною вибіркою було опитано 1125 респондентів. Теоретична похибка вибірки становить 3\%. Обробка анкет велася за допомогою програми «ОСА».

Результати. Дослідження показало, щзо лише половина опитаних жителів об'єднаних територіальних громад позитивно оцінюють свій стан здоров'я, а майже 57\% населення зазначають, щчо в основному не піклуються про власне здоров'я. 78\% опитаних відповідальність за своє здоров'я покладають на зовнішні, незалежні від них чинники і тільки 21,8\% згодні, щчо їх здоров'я залежить від способу життя. Більш того, респонденти не відносять до пріорітетних такі проблеми охорони здоров'я як виховання та дотримання здорового способу життя, боротьбу зі шкідливими звичками і відмічають їх лише на рівні 6\%. Кожен другий респондент вказав, щуо має хронічні захворювання, серед яких перше місие займають сериево-судинні. Проте тільки 31\% відповіли, щуо контролюють свій артеріальний тиск.

Висновки. Ефективна профілактика хронічних неінфекційних хвороб базується на виявленні та усуненні факторів ризику розвитку захворювань, а також формуванні активного суспільства. Відтак, актуальним є питання розробки $i$ впровадження сучасних інформаційно-комунікаційних технологій для дистанційного зв'язку паџієнта із надавачем медичних послуг на рівні первинної ланки охорони здоров'я, щзо дасть можливість покращити динамічне спостереження та підвищити відповідальність населення за власне здоров'я.
\end{abstract}

Ключові слова: профілактика захворювань, хронічні неінфекиійні захворювання, охорона здоров'я населення, інформаційно-комунікаційні технології.

\section{Вступ}

3 доров’я населення $є$ однією 3 найбільших цінностей та необхідною умовою для соціально-економічного розвитку країни. Профілактика хвороб і формування активного суспільства є важливою складовою трансформації системи охорони здоров'я в Україні. Здоров'я сьогодні розглядається як фактор дотримання демократичних прав, соціальної стабільності та легітимності держави. У стратегії “Здоров’я-2020” одним із головних пріоритетів напрямів дій визначено «Інвестування в здоров’я на всіх етапах життя людини і розширення прав i можливостей громадян» [1]. В документі зазначається, що підтримка здоров'я та його соціальних детермінант протягом всього життя веде до зростання очікуваної тривалості здорового життя, що дає серйозні економічні, соціальні та індивідуальні вигоди. Тому формування здорового способу життя, складовою якого $\epsilon$ профілактика захворювань залишається пріоритетною проблемою як на світовому, так i на національному та регіональному рівнях.

Дослідження, які стосуються формування здорового способу життя та профілактики хронічних неінфекційних захворювань присвячені праці (Москаленко В.Ф., 2013; Григоренко А.А., 2013; Грузєва Т.С., 2013).
Як відомо, профілактика - комплекс заходів, спрямованих на збереження й зміцнення здоров'я, які включають формування здорового способу життя, попередження виникнення i/aбо поширення захворювань, ïх раннє виявлення, встановлення причин i умов їх виникнення й розвитку, а також спрямованих на усунення шкідливого впливу на здоров'я людини факторів середовища її проживання [2].

Ефективна профілактика захворювань насамперед базується на виявленні та усуненні факторів ризику. ВОО3 визначає фактор ризику як «певну властивість або особливість людини або який-небудь вплив на неї, що підвищує імовірність розвитку хвороби або травми» [3]. Найчастіше фактори ризику поділяють на: такі, що такі, що не коригуються (не модифіковані), вплинути на які неможливо - стать, вік, обтяжена спадковість та такі, що коригуються або модифікуються (модифіковані). Вплив на модифіковані фактори ризику можливий в результаті проведення тих або інших профілактичних програм куріння, зловживання алкоголем, підвищення артеріального тиску (АТ), хронічний стрес, надлишкова маса тіла, підвищення рівня холестерину у крові, знижена рухова активність, професійні шкідливості [4].

Як показують результати міжнародних досліджень, профілактика захворювань i зміцнення здоров'я, ефективні тільки тоді, коли здійснюються як медичними, так і немедичними методами [5]. Крім того варто 
наголосити, що збереження здоров'я являється не тільки медичною, а і соціальною проблемою та залежить від відповідальності самого пацієнта за стан свого здоров'я. Тому актуальним буде проведення соціологічного дослідження щодо відповідальності населення об'єднаних територіальних громад (ОТГ) Сумської області за стан власного здоров'я, уявлення щодо профілактики захворювань та пріоритетних питань в охороні здоров'я громади. Також доцільність розробки і впровадження сучасних інформаційно-комунікаційних технологій для дистанційного зв'язку пацієнта із надавачем медичних послуг на рівні первинної ланки охорони здоров'я, що дасть можливість покращити динамічне спостереження та підвищити відповідальність населення за власне здоров'я.

Мета - дослідити ставлення населення об'єднаних територіальних громад Сумської області до проблем профілактики захворювань та збереження власного здоров'я.

\section{Матеріали та методи}

Дослідження проводилося кафедрою громадського здоров'я медичного інституту Сумського державного університету та Центральною Сумською районною лікарнею у співпраці з Проблемною лабораторією «Центр соціально-гуманітарних аспектів регіональних досліджень» Сумського державного університету протягом жовтнялистопада 2018.

Форма дослідження - опитування за допомогою закритої анкети. Дослідження проводилося за спеціально розробленою трирівневою пропорційною вибіркою, яка розраховувалась 3 врахуванням територіальних i соціально-демографічних показників. Всього за пропорційною вибіркою було опитано 1125 респондентів ОТГ Сумської області. Розподіл респондентів за віком і статтю представлений в таблиці. Теоретична похибка вибірки становить $3 \%$.

Дослідження проводилося у два етапи. На першому етапі були розроблені програма та інструментарій, сформована вибірка, а також розроблені маршрути. На другому етапі проведено польові роботи (збір інформації, перевірка роботи інтерв'юерів, вибракування анкет), комп'ютерна обробка, сформовані таблиці і підготовлено звіт. Обробка анкет велася співробітниками лабораторії за допомогою програми «ОСА».

Табличя

Розподіл пацієнтів за віком і статтю, \%

\begin{tabular}{|c|c|c|c|}
\hline Вік & Чоловік & Жінка & $\begin{array}{c}\text { Не } \\
\text { відповіли }\end{array}$ \\
\hline 18-29 років & 50 & 50 & 10 \\
\hline 30-39 років & 45,3 & 54,7 & 13,7 \\
\hline 40-49 років & 46,7 & 53,3 & 6,4 \\
\hline 50-59 років & 40,3 & 59,8 & 3,7 \\
\hline 60-69 років & 39,3 & 60,7 & 1,8 \\
\hline $70-79$ років & 30,8 & 69,2 & 2,6 \\
\hline
\end{tabular}

\section{Результати дослідження та їх обговорення}

На основі обробки та аналізу отриманої інформації можна зробити такі узагальнення і висновки.

На запитання «Як би Ви оцінили своє здоров'я?» лише 42,7\% опитаних зазначили «добре» і ще 8,2\% «дуже добре». Проте 8,8\% опитаних оцінили своє здоров'я як «погане», а 39,7\% взагалі не змогли оцінити стан свого здоров'я (32,8\% відповіли «ані хороше, ані погане», 5\% «важко сказати»). Такі результати свідчать про те, що біля $40 \%$ населення не цікавиться власним здоров'ям (рис. 1).

Підтвердженням отриманих вище даних є відповіді респондентів на питання «Якою мірою Ви піклуєтесь про стан свого здоров'я?» (рис. 2). Так, лише 10,5\% респондентів відповіли, що піклуються про стан свого здоров'я «дуже добре», а 32,6\% - «скоріше добре». При цьому кожен другий респондент $(56,7 \%)$ недостатньо піклується про власне здоров'я: $31,7 \%$ опитаних зазначають, «посередньо» піклуються, а біля 25\% зізнаються, що зовсім не піклуються про своє здоров'я.

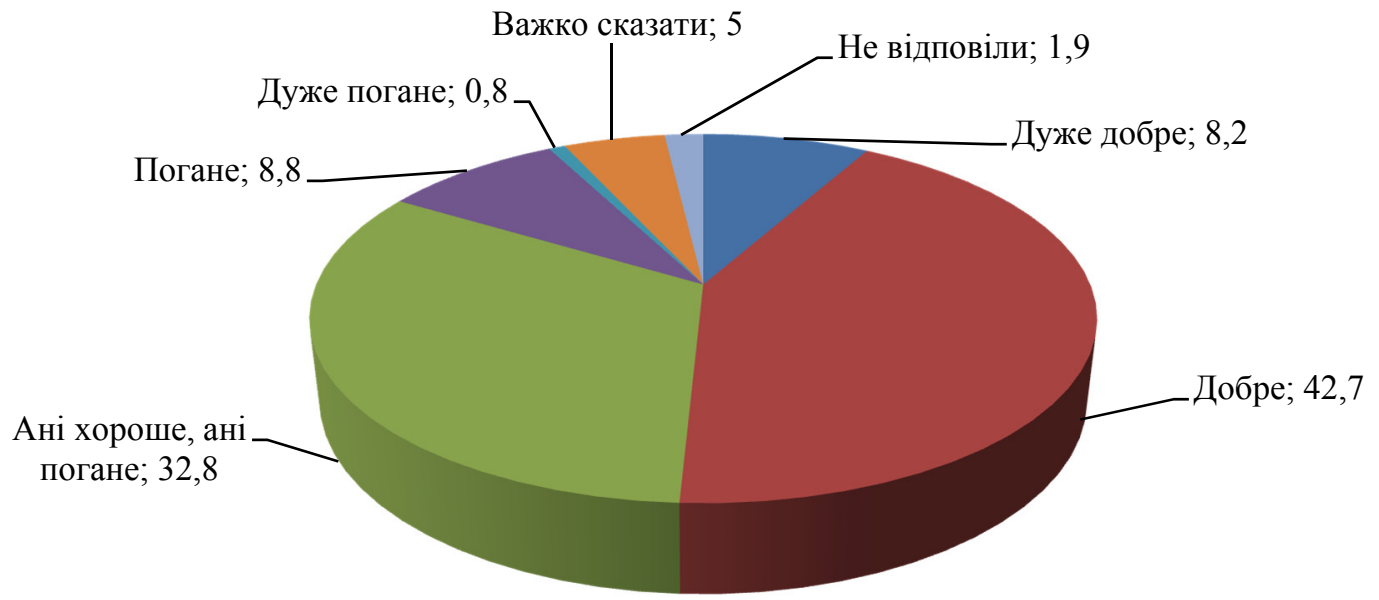

Рис. 1. Оцінка респондентами власного здоров'я, \% 


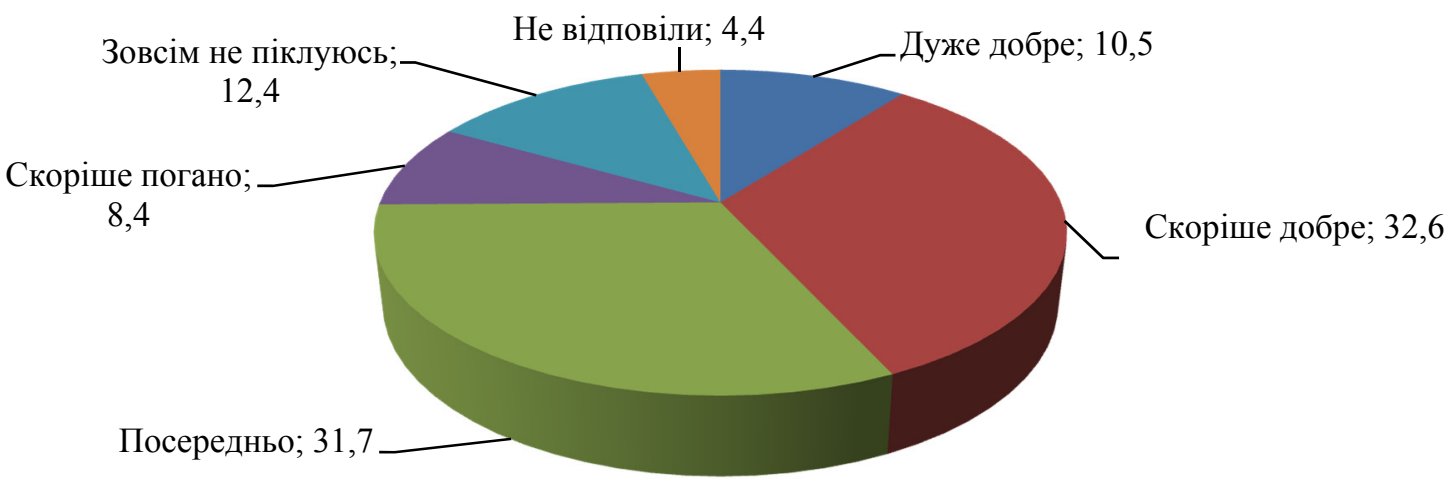

Рис. 2. Якою мірою респонденти піклуються про своє здоров'я, \%

Дослідження показало, що біля 70\% населення ОТГ обрали сімейного лікаря та уклали 3 ним декларацію. Проте в разі захворювання тільки $18,3 \%$ опитаних вказали, що в першу чергу звертаються за медичною допомогою до сімейного лікаря, ще 8,4\% звертаються до лікарів вузького профілю, а 7,1\% викликають машину швидкої допомоги. Більша частина опитаних $(60,3 \%)$ зазначили, що взагалі не звертаються за медичною допомогою в заклади охорони здоров'я, 3 яких $38,2 \%$ - займаються самолікуванням; $11,8 \%$ - лікуються народними методами; 9,5\% - просять поради в аптеці; 0,8\% - шукають поради в Інтернеті (рис. 3).

Респонденти, які не обрали сімейного лікаря вказали, що причиною цього $є$ їхнє особисте небажання укладати декларацію саме зі своїм лікарем (40\%) та брак часу для заключення договору (27\%).

Зазначений розподіл відповідей може свідчити про обмежений вибір сімейних лікарів в ОТГ, особисту недовіру пацієнтів до свого лікаря та недостатню відповідальність населення за своє здоров'я.

За останні роки серед населення ОТГ спостерігається збільшення захворюваності на хронічну неінфекційну патологію (ХНI3), так за I півріччя 2019 року серед населення ОТГ Сумської області зберігається негативна динаміка щодо смертності від неінфекційної патології, а саме серцево-судинних захворювань: збільшення на 69,2\% показника смертності від інфаркту міокарда - 0,22 на 1 тис. нас. (I півр. 2018 р. - 0,13 на 1 тис. нас.; збільшення на 3,4\% показника смертності від інсультів - 0,6 на 1 тис. нас. (I півр. 2018 р. - 0,28 на 1 тис. нас.) [6].

Для нас цікавою стала думка та розуміння респондентів, які саме чинники негативно впливають на стан ї здоров'я та можуть стати факторами ризику розвитку захворювань, а також їх відношення до профілактики неінфекційних хвороб.

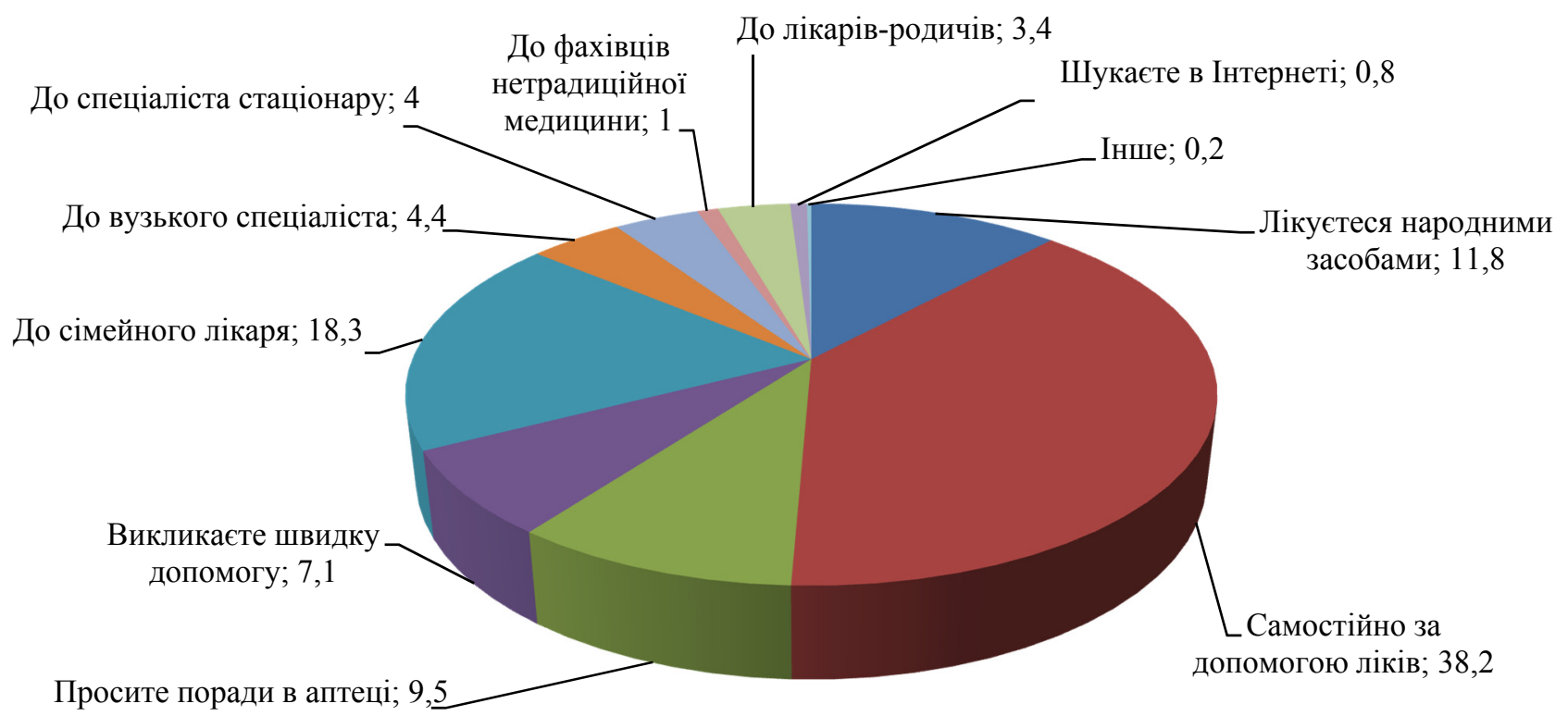

Рис. 3. Розподіл відповідей на питання «Що Ви, як правило, робите в першу чергу, коли захворіли?», \%

Дослідження показало, $73 \%$ опитаних погоджуються про важливість проблеми профілактики захворювань.
Однак, респонденти головним чином відповідальність за погіршення стану свого здоров'я покладають на зовнішні 
чинники, а не на себе. Тільки 25,3\% респондентів відмітили неправильне харчування та нестачу фізичного навантаження, $21,8 \%$ - шкідливі звички, а 15,6\% «неуважність до самого себе» як основні негативні чинники, що впливають на їх здоров'я. 49,8\% відмітили психологічне напруження одним 3 основних негативних чинників; 37,4\% - екологічні проблеми та навколишне середовище; 19,1\% економічні проблеми; 19,7\% - умови праці (рис. 4).

Такі результати свідчать про недостатню власну відповідальність пацієнтів за стан свого здоров'я та нерозуміння населенням проблеми профілактики захворювань.
Кожен другий опитаний зазначає, що має хронічні захворювання (рис. 5): серцево-судинні захворювання $(32,3 \%)$; хронічний гайморит, отит, фарингіт, тонзиліт $(11,6 \%)$; цукровий діабет $(3,4 \%), 10 \%$ зазначили, що мають інші хронічні захворювання. Такі результати співвідносяться із першим питанням анкети, де так само тільки половина опитаних позитивно оцінили свій стан здоров'я.

Однак при такому високому рівні захворюваності на хронічну неінфекційну патологію $31 \%$ опитаних відповіли, що не контролюють свій артеріальний тиск (рис. 6).

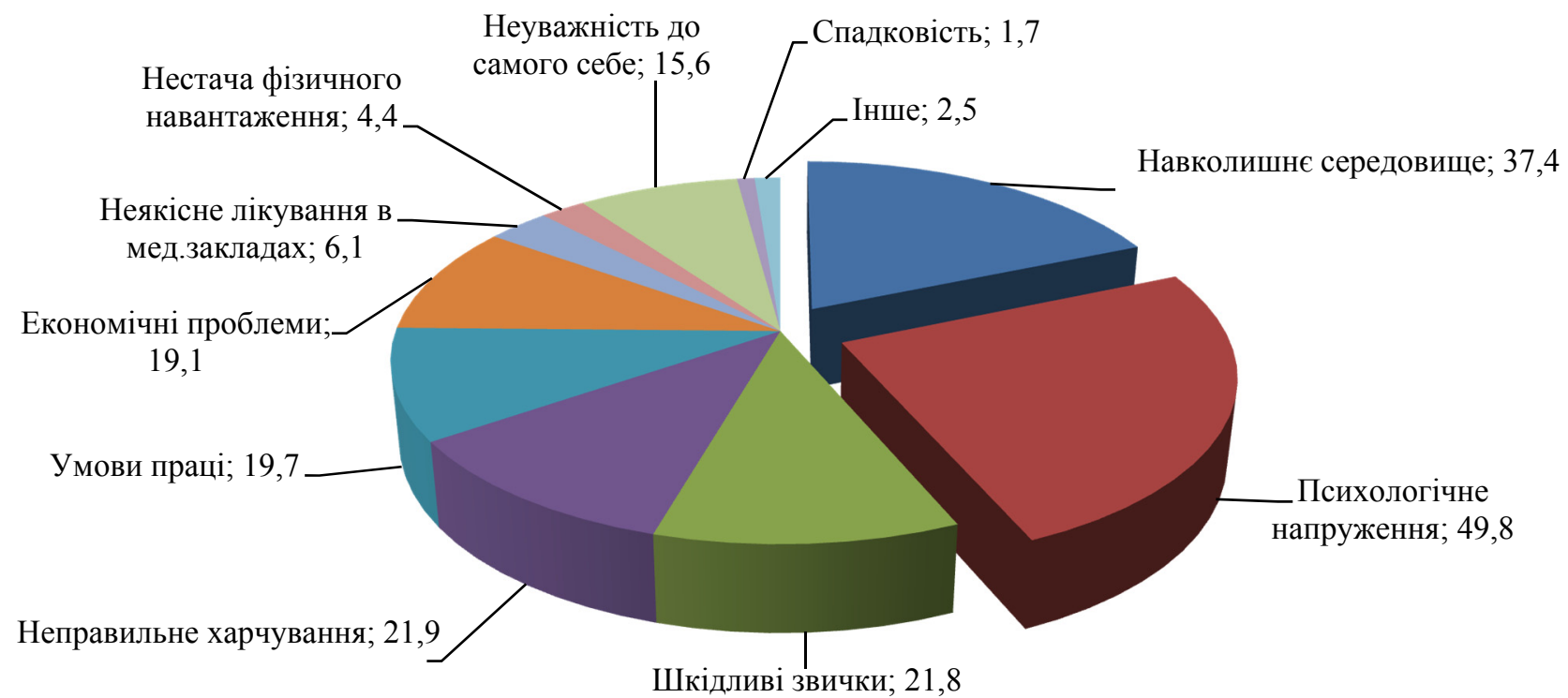

Рис. 4. Розподіл відповідей на питання «Що, на Вашу думку, негативно впливає на стан Вашого здоров’я?», \%

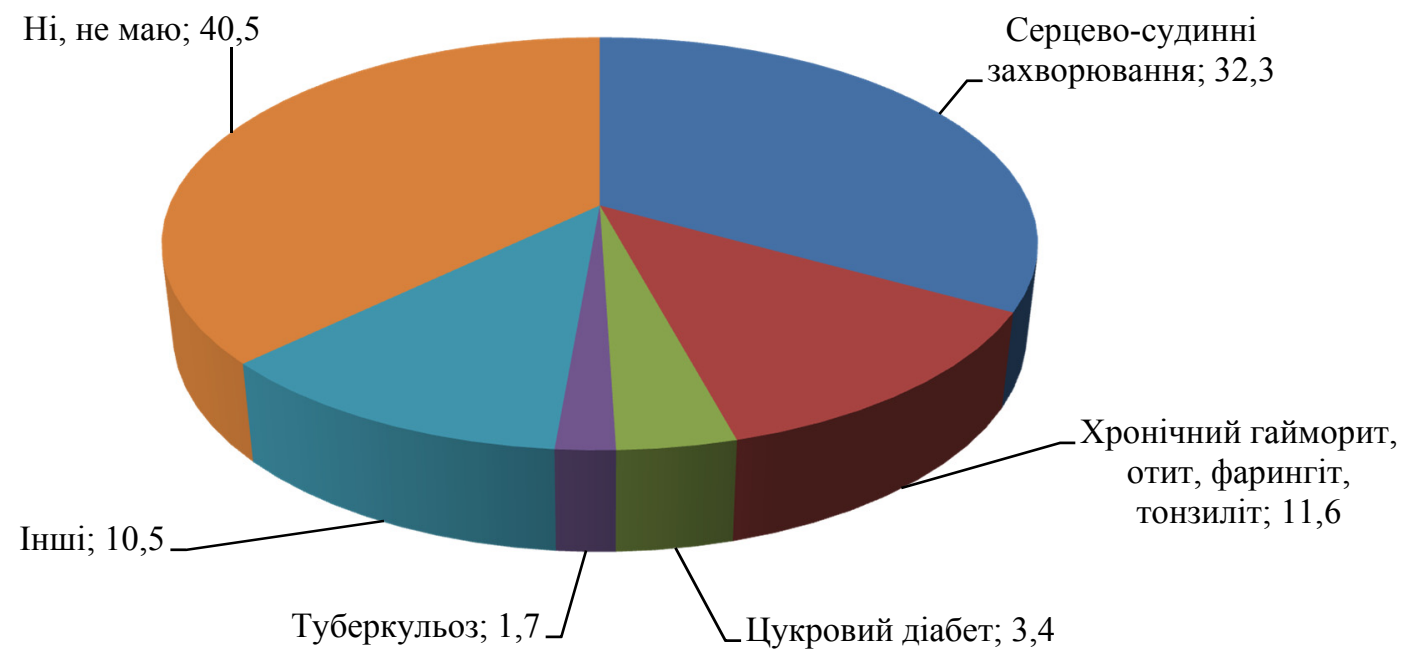

Рис. 5. Розподіл респондентів за наявністю хронічних захворювань, \% 
Серед тих респондентів, хто перевіряє артеріальний тиск, 27,2\% роблять це кожного дня; $30 \%$ - раз на тиждень; $19 \%$ - раз на місяць, а 13\% - раз на рік (рис. 7). При цьому майже всі респонденти $(98,3 \%)$ вказали, що мають особисті прилади вимірювання артеріального тиску.

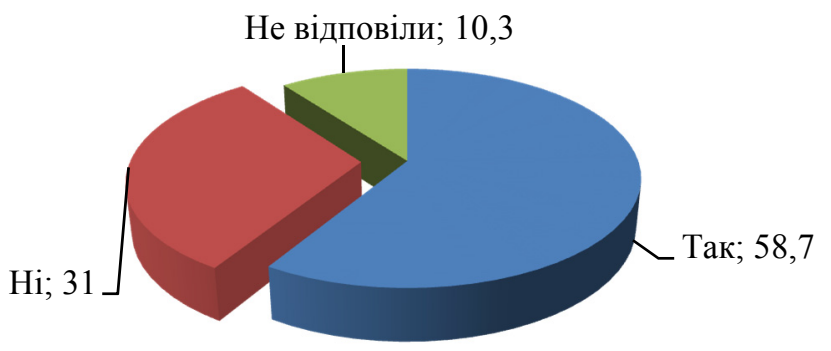

Рис. 6. Розподіл відповідей на питання «Ви перевіряєте чи не перевіряєте свій артеріальний тиск», \%

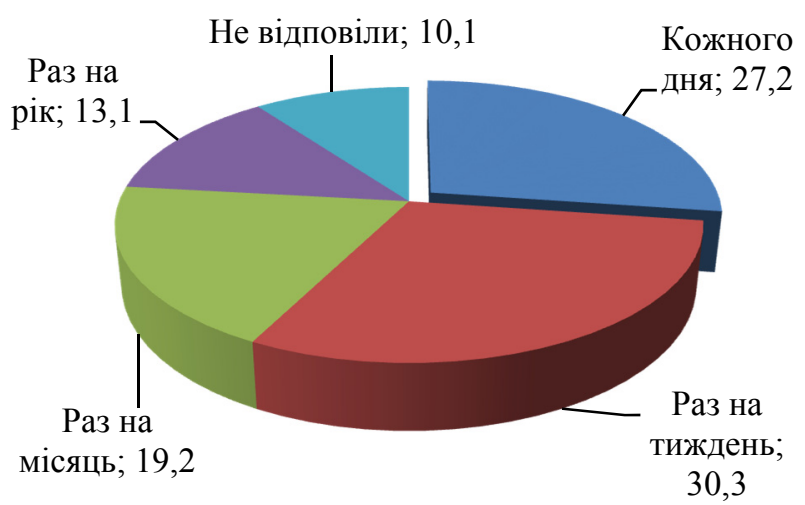

Отримані дані свідчать про те, що майже половина населення $\epsilon$ неактивною у відношенні профілактики ХНІЗ та існує необхідність у розвитку і впровадженні сучасних інформаційно-комунікаційних систем для бажаного дистанційного двостороннього зв'язку пацієнта із надавачем медичних послуг для покращення відповідальності пацієнта за стан свого здоров'я і, що найбільш важливо, сприятиме залученню його в процес динамічного спостереження.

Слід зазначити, що респонденти вважають актуальним питання збереження і покращення здоров'я людей в громаді, адже $81 \%$ дали стверджувальну відповідь.

В той же час серед найбільш важливих проблем в охороні здоров'я жителі громади на перше місце ставлять матеріальне забезпечення амбулаторії (44\%), на друге місце - транспортне сполучення (18\%), на третє - кадрове забезпечення амбулаторії (16\%) (рис. 8). А такі проблеми як виховання та дотримання здорового способу життя, боротьба зі шкідливими звичками респонденти не відносять до пріорітетних і відмічають їх лише на рівні $6-2 \%$.

Дослідження показало, що існує проблема усвідомлення відповідальності населення громади за збереження власного здоров'я та нерозуміння важливості проведення ефективної інформаційної кампанії щодо профілактики захворювань.

Рис. 7. Розподіл респондентів за частотою

вимірювання артеріального тиску, \%

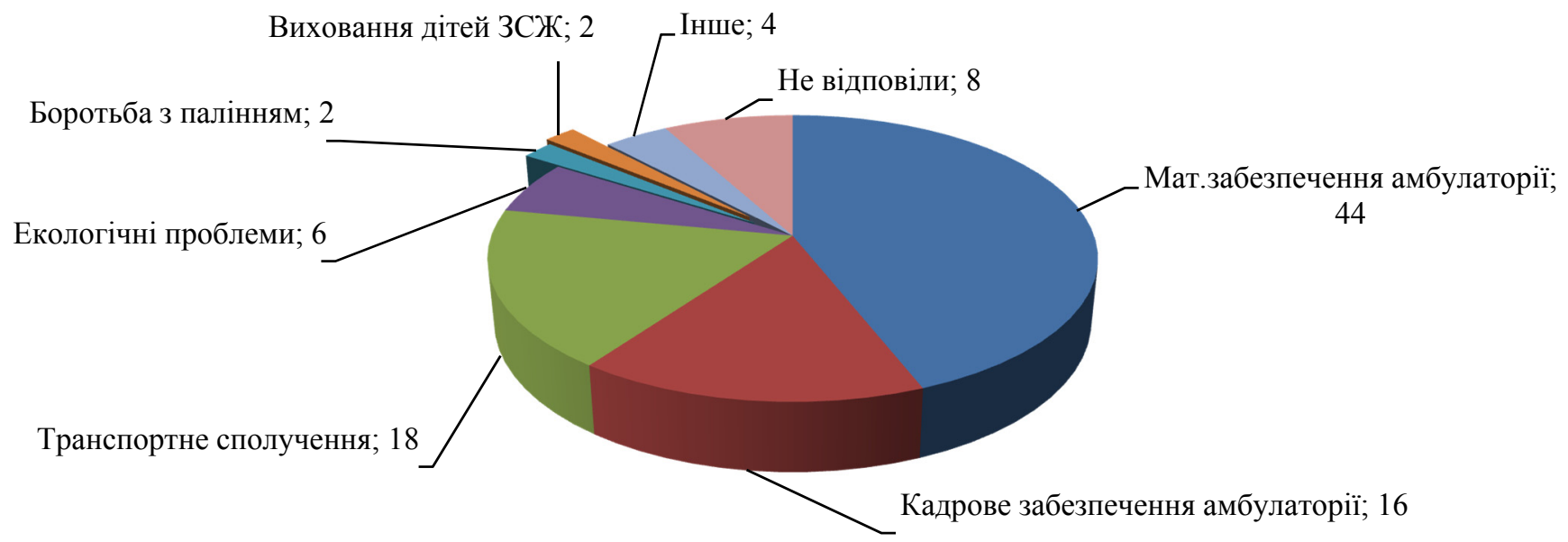

Рис. 8. Розподіл відповідей на питання «Які проблеми охорони здоровя актуальні у Вашій громаді?», \%

\section{Висновки}

1. Лише половина опитаних жителів ОТГ позитивно оцінюють свій стан здоров'я, а майже 57\% населення зазначають, що в основному не піклуються про власне здоров'я.

2. 78\% опитаних відповідальність за своє здоров'я покладають на зовнішні, незалежні від них чинники і тільки 21,8\% згодні, що їх здоров'я залежить від способу 
життя. Більш того, респонденти не відносять до пріорітетних такі проблеми охорони здоров'я як виховання та дотримання здорового способу життя, боротьбу зі шкідливими звичками і відмічають їх лише на рівні 6\%. Такі результати свідчать про недостатне розуміння населенням проблеми збереження здоров'я та профілактики ХНІЗ.

3. Третина населення не уклали декларацію із сімейним лікарем, пояснюючи це тим, що не мають часу або висловлюючи особисту недовіру до свого лікаря. В разі захворювання лише $18,3 \%$ опитаних в першу чергу звертаються до сімейного лікаря. Кожен другий мешканець вдається до самостійного лікування.

4. Кожен другий респондент вказав, що має хронічні захворювання, серед яких перше місце займають серцево-судинні. Проте тільки $31 \%$ відповіли, що контролюють свій артеріальний тиск.

5. Актуальним є питання розробки і впровадження сучасних інформаційно-комунікаційних технологій для дистанційного зв'язку пацієнта із надавачем медичних послуг на рівні первинної ланки охорони здоров'я, що дасть можливість покращити динамічне спостереження та підвищити відповідальність населення за власне здоров’я.

\section{Література}

1. “Здоров’я-2020”: Основи Свропейської стратегії у підтримку дій всієї держави і суспільства в інтересах здоров'я і благополуччя. - Копенгаген : СРБ ВООЗ, 2012.

2. Загальна теорія здоров'я та здоров'язбереження : колективна монографія / за заг. ред. проф. Ю. Д. Бойчука. - Харків: Вид. Рожко С. Г., 2017. - 488 с.

3. Факторы риска. Вопросы здравоохранения // Всемирная организация здравоохранения / URL: http://www.who.int/topics/risk_factors/ru/ (дата звернення: 20.07.2017).

4. Здоровыци образ жизни и профилактика заболеваний / Под ред. Ющука Н.Д., Маева И.В., Гуревича К.Г. М. : Изд-во «Перо», 2012. - 659 с., с. 63.

5. Здоровый образ жизни и профилактика заболеваний / Под ред. Ющука Н.Д., Маева И.В., Гуревича К.Г. М. : Изд-во «Перо», 2012. - 659 с., с. 60-61.

6. Матеріали колегії управління охорони здоров’я Сумської державної адміністрації від 11.07 .2019 року «Аналіз діяльності галузі охорони здоров’я Сумського району за І півріччя 2019 року».

Дата надходження рукопису до редакиї: 02.10.2019 p.

\section{Медико-социологическое исследование среди населения объединенных территориальных общин Сумской области по сохранению собственного здоровья}

Дрыга Н.А., Почелуев В.И., Смеянов В.А., Костенко А.Н. Сумский государственный университет, г. Сумы, Украина

Цель - проанализировать отношение населения объединенных территориальных общин к сохранению собственного здоровья, профилактики неинфекционных заболеваний и приоритетных вопросов в здравоохранении общины.

Материалы и методы. Форма исследования опрос с помощью закрытой анкеты. Исследование проводилось по специально разработанной трехуровневой пропорциональной выборке, рассчитывалась с учетом территориальных и социально-демографических показателей. Всего по пропорциональной выборке было опрошено 1125 респондентов. Теоретическая погрешность выборки составляет $3 \%$. Обработка анкет велась сотрудниками лаборатории «Центр социальногуманитарных аспектов региональных исследований»
Сумского государственного университета с помощью программы «ОСА».

Результаты. Исследование показало, что лишь половина опрошенных жителей объединенных территориальных общин положительно оценивают свое состояние здоровья, а почти 57\% населения отмечают, что в основном не заботятся о собственном здоровье. $78 \%$ опрошенных ответственность за свое здоровье возлагают на внешние, независимые от них факторы и только 21,8\% согласны, что их здоровье зависит от образа жизни. Более того, респонденты не относят к приоритетным такие проблемы здравоохранения как воспитание и соблюдения здорового образа жизни, борьбу с вредными привычками и отмечают их на уровне $6 \%$. Каждый второй респондент указал, что имеет хронические заболевания, среди которых первое место занимают сердечно-сосудистые. Однако только 31\% ответили, что контролируют свое артериальное давление.

Выводы. Эффективная профилактика хронических неинфекционных болезней базируется на выявлении и устранении факторов риска развития заболеваний, а также формировании активного общества. Поэтому сохранения здоровья является не только медицинской, но и социальной проблемой и зависит от ответственности самого пациента за собственное здоровье. Разработки и 
внедрения современных информационнокоммуникационных технологий для дистанционной связи пациента с предоставляющим медицинских услуг на уровне первичного звена здравоохранения, что позволит улучшить динамическое наблюдение и повысить ответственность населения за собственное здоровье.

Ключевые слова: профилактика заболеваний, хронические неинфекционные заболевания, охрана здоровья населения, информационно-коммуникационные технологии.

\section{Medical sociological research among inhabitants of Sumy region united communities on self-healthcare}

Dryha N.O., Potseluiev V.I., Smiyanov V.A., Kostenko A.M. Sumy State University, Sumy, Ukraine

Formation of health life and disease prophylaxis remain a top-priority problem at all levels of organization: global, national or regional. Population health is one of the biggest value and, at the same time, is a needed circumstance for country`s socio-economic development. Effective prophylaxis of chronic non-communicable diseases is most based on finding and elimination of illness risk but also requires formation of active society. Thus, healthcare appears not only as a medical aim but also as a social problem that makes patient himself responsible for his health state.

Purpose - to learn more about attitude of Sumy region communities to the problem of prophylaxis and idea of selfhealthcare.

Materials and methods. Our investigation form questionnaire. We made our research based on three-level proportional selection, that varied due to the territory and socio-demographical indexes. Totally, we have questioned 1125 inhabitants. Theoretical error of selection equals 3\%.

The research was done in two steps. During first step, we have designed and set program, instruments, formed selection features and created routes. During second part, our work was to make field studying (information gathering, interviewers`work check and eliminating of question forms) with further computer processing, combining material into the tables and preparation of report. Question forms ' processing was done by Sumy State university laboratory "Center of socio-humanitarian regional researches' aspects" and with "OCA" program.

Results. After research we have concluded that only half of inhabitants of communities can rate their health state as positive and about $57 \%$ of them have indicated that they do not take care of their health themselves. About $78 \%$ of questioned people preferred to answer that their health is a responsibility of some out, independent factors, and only $21.8 \%$ agreed that their health depends on their way of life. Moreover, respondents do not consider such problems of public healthcare as health education, keeping healthy lifestyle, elimination of bad habits to be preferential; they put them only as $6 \%$ important. Every second respondent also claimed to have chronic disease, among them heart system diseases rated first. Nevertheless, only $31 \%$ of them are keeping their blood pressure control. Thus, we can say that today we have to create and implement informational communicative technologies for distance contact of patient and medical specialist. This will allow improving dynamic researches levels and will start improving of patients' attitude to their health and selfhealthcare.

Key words: disease prophylaxis, chronic non-communicable diseases, public healthcare, informational communicative technologies.

\section{Відомості про авторів}

Дрига Наталія Олександрівна - аспірант кафедри громадського здоров’я Медичного інституту Сумського державного університету; вул. Праці 3, м. Суми, 40004, Україна.

Поцелусв Володимир Іванович - головний лікар Комунального некомерційного підприємства «Сумська центральна районна клінічна лікарня» Сумської районної ради Сумської області Сумський район; вул. Паркова 2А, с. Сад, Сумський район, Сумська обл., 42343, Україна.

Сміянов Владислав Анатолійович - д. мед. н., проф., завідувач кафедри громадського здоров’я Медичного інституту Сумського державного університету; вул. Праці 3, м. Суми, 40004, Україна.

Костенко Андріана Миколаївна - к. політ. н., доцент кафедри філософії, політології та інноваційних соціальних технологій Сумського державного університету; вул. Римського-Корсакова, 2, м. Суми, 40007, Україна. 